\title{
Çocukluk Çağı Akut Lenfoblastik Lösemileri
}

\author{
Childhood Acute Lymphoblastic Leukemia
}

\author{
Kadir YÜMLÜ \\ Türkiye Kamu Hastaneler Kurumu Demirci Devlet Hastanesi, Çocuk Sağlığı ve Hastalıkları Kliniği, Manisa
}

\section{ÖZET}

Akut lenfoblastik lösemi çocukluk çağının en çok görülen kanserlerinden birisidir. Erkek çocuklarda daha sık görülür. Etiyopatogenezinde genetik bozuklukla giden bazı hastalıklar, kimyasal ajanlara maruziyet ve bazı kromozomal anomaliler sorumlu tutulmuştur. Hastalık ilk olarak halsizlik, solukluk, kanama ve ateş gibi nonspesifik belirtilerle kendini gösterir. Fizik muayenede en çok lenfadenopati, hepatosplenomegali, solukluk ve cilt döküntüleri izlenir. Tanısı fizik muayene, periferik kan ve kemik iliği incelemesi ile konulur. Tedavide risk yönelimli kemoterapi protokolleri ile bir yandan yan etkiler azaltılırken diğer yandan yaşam oranları artırılmaktadır. Son yıllarda yapılan bazı çalışmalarda 5 yıllık sağ kalım oranları $\% 80$ 'ler düzeylerine çekilmiştir.

Anahtar Kelimeler: Çocuk, lösemi, lenfoblastik.

\section{GiRiş}

Akut lösemiler, kemik iliği (KI) öncü hücrelerinin kontrolsüz şekilde çoğalmalarıyla, Ki ve vücudu istila etmesi sonucu gelişen malign seyirli bir hastalıktır. İmmatür hücreler KI’ni infiltre ederek Ki yetmezliğine neden olurken, bu durum çevre kanına anemi, trombositopeni, lökopeni veya lökositoz olarak yansır. Çevre kanındaki bu değişiklikler hastalarda solukluk, halsizlik, kanama, ateş ve ciddi enfeksiyon gibi klinik bulgulara neden olabilir (1).

Akut lösemiler lenfoid ve miyeloid olarak iki grupta ele alınırken, çocukluk çağı malign olaylarının \%30’unu oluşturmaktadırlar. Uzun süreden beri yapılan

Yazışma Adresi / Correspondence: Uzm. Dr. Kadir YÜMLÜ Adres: Demirci Devlet Hastanesi Çocuk Hastalıkları Servisi,Manisa/ Demirci

e-mail: drkyumlu@hotmail.com

\section{ABSTRACT}

Acute lymphoblastic leukemia is one of the most common group of cancers in childhood. It is more common in males. In the pathogenesis, some diseases with genetic disorders, exposure to chemical agents, and some chromosomal abnormalities have been thought to be responsible. The disease initially presents with nonspecific symptoms such as weakness, paleness, bleeding and fever. Diagnosis of the disease is made by physical examination and analiysis of peripheral blood and bone marrow biopsy. Risk-oriented protocols of chemotherapy reduces side effects while increasing survival rates. In recent years, 5 -year survival rates have reached up to $80 \%$ in some studies.

Keywords: Acute, leukemia, lymphoblastic.

çalışmalar neticesinde tedavi başarısı \%80'ler düzeyine çıkmıştır. Son dönemde lösemilerin tedavisinde risk yönelimli tedavi protokolleri kullanılmakta olup, bununla hem hastalarda olaysız sağ kalım oranları arttırılmaya çalışılmakta hem de verilen tedavilerin toksik etkilerinin azaltılması amaçlanmaktadır.

\section{EPIDEMIYOLOJi}

Akut lösemi çocuklarda en sık görülen malignitedir. Amerika Birleşik Devletlerinde 15 yaşından küçüklerde Akut Lenfoblastik Lösemi (ALL) görülme sıklığı 3.4/100000'tür. Ülkemizde sıklığı 1.4/100000 olarak tahmin edilmektedir (1- 3). ALL en sık 2-6 yaşlar arasında izlenirken, Akut Miyeloblastik Lösemi (AML) sıklığı 0-2 yaş ve adölesan yaş grubunda pik yapar. Çocukluk çağı ALL olgularında erkek/kız oranı 1.2-1.4 
olarak bulunmuştur. Cinsiyet dağılımındaki fark pubertal dönemde daha belirgindir. $\mathrm{Bu}$ dönemde erkeklerdeki ALL sıklığı 1.2'den 2'ye kadar yükselir (2).

\section{ETIYOPATOGENEZ}

Akut lenfoblastik löseminin etiyolojisi tam olarak belli değildir. Lösemi klonal bir hastalık olup, tek bir hücre grubunun aşırı ve kontrolsüz çoğalması sonucu Kíni ve kan yoluyla yayılarak diğer organları istila etmesiyle klinik bulgulara yol açmaktadır. Pek çok risk faktörü ortaya konulmuştur. Bunlardan en iyi bilinenler iyonize radyasyon, bazı kimyasal moleküllere maruziyet ve bazı genetik hastalıklardır. Down sendromu, Bloom sendromu, Fanconi aplastik anemisi ve Klinifelter sendromu bunlardan bazılarıdır. Genetik olarak bazı karyotipik bozukluklar ve translokasyonların da akut lösemi etiyolojisinde rol oynadıkları gösterilmiştir. Tüm bu etiyolojik faktörler tümör süpresör genlerde ve apopitozisi sağlayan genlerde fonksiyon kaybına, protoonkogenlerde ise aktivite artışına neden olmaktadır. Bunun sonucunda lenfoblastların farklılaşmaları bozulmakta ve hızlı çoğalma özelliği kazanmaktadır $(3,4)$.

\section{Sınıflandırma:}

Illk olarak 1976 yılında Fransız, Amerikan ve İngiliz hematologları, ALL olguların periferik yayma ve Ki aspirasyon yaymalarındaki hücrelerin morfolojik olarak incelemeleriyle FAB klasifikasyonunu oluşturmuşlardır. Bu klasifikasyonda; hücrelerin büyüklüğü, çekirdek şekli, çekirdekçik sayısı, sitoplazmalarının bazofili derecesi esas alınmış ve 1981 yılında da güncellenmiştir (5).

FAB L1: Hücreler homojen ve küçük olup, sitoplazmaları hafif bazofilik ve dardır. Çekirdek sınırları düzenlidir ve çekirdekçik belirsizdir. Sitoplazmada değişik düzeyde vakuolizasyon izlenebilir. L1 morfolojisi çocukluk çağı lösemi vakalarının \%80 kadarını oluşturmaktadır (5).

FAB L2: Hücreler heterojen ve daha büyük olup, sitoplazmaları daha geniştir. Değişken derecelerde bazofilik boyanır. Çekirdek sınırları düzensizdir. Çekirdekçik belirgin olup, bir veya daha fazla sayıdadır. L2 morfolojisi vakaların \%15'inde izlenmekte olup genelde erişkin tip lösemilerde daha sık görülür (5-9).
FAB L3: Hücreler homojen ve büyük olup, sitoplazmaları koyu, bazofilik görünümlü ve geniştir. Sitoplazmada belirgin vakuolizasyon vardır. Çekirdek yuvarlak, sınırları düzenlidir. Çekirdekçik bir veya daha fazla sayıda büyük veziküller içerir. Bu hücrelerde mitoz sıktır. Burkit lösemi buna örnek verilebilir $(5,7,9,10)$.

Lenfoblastlar, granülosit ve monositlerin içerdikleri enzim aktivitelerini göstermezler. $\mathrm{Bu}$ nedenle peroksidaz, sudan black (SB), klor asetat esteraz ve nonspesifikesteraz sitokimyasal boyaları ile boyanmazlar. Lenfoblastların yarısı periodic acid schiff (PAS) ile boyanırken, \%90 oranında terminal deoksinükleotil transferaz (TdT) enzimi içerip anti TdT ile boyanma gösterir. TdT nükleer bir enzim olup yıllarca tanıda kullanılan en önemli belirteç olagelmiştir.

\section{İmmunolojik sınıflama:}

İmmünolojik sınıflama lenfositlerin yüzeylerinde ve stoplazmasında bulunan Cluster of Diferantiation (CD) olarak adlandırılan lenfoid farklılaşma antijenlerinin flowsitometrik incelenmesine göre yapılır. B hücre immünfenotipi CD19, CD79a veya sitoplazmik CD22 belirteçlerinden en az ikisinin ekspresyonunun yanında $T$ hücre ve miyeloid hücre belirteçlerinin ekspresyonlarının olmaması ile karakterizedir. CD10 (CALLA: "common leukemia-associated antigen") ALL sınıflamasında önemli bir belirteç olup vakaların $\% 80$ 'ninde izlenir. Ayrıca CD20, sitoplazmik $\mu$ ü ve yüzeyel İgM, B hücreli ALL'nin diğer belirteçlerindendir.T hücre immünfenotipi ise $C D 3, C D 7$ ve $C D 2$ ekspresyonu ile tanınır $(2,7,11)$.

\section{A-B Hücreli Akut Lenfositik Lösemi}

1-Pro B ALL:Tüm B immünfenotipik lösemi grubunun \%5'lik kısmını oluşturup, CD10 antijeni negatiftir. Infant ve yetişkinlerde sıklı̆ı fazla iken tanı anında yüksek beyaz küre sayısı, merkezi sinir sistemi (MSS) tutulumu sıktır. Yüksek lökosit sayısı, düşük yaş ve MSS tutulumları da kötü prognostik özelliklerdir. $(2,8,12$ 14).

2-Common ALL: Lenfoblastlar CD10 CALLA antijeni adı verilen membran antijenini taşırlar. Membran ve intrastoplazmik immünglobulinler ile $\mathrm{T}$ hücre antijenleri yoktur. TdT pozitiftir. Çocukluk dönemi ALL'lerinin yaklaşık \%65'ini oluşturur. Bu grupta tanı sırasında genellikle lökosit sayısı düşük olup, 
sitogenetik olarak da hiperdiploidi ile birliktelik gösterir. Bu iyi prognostik özellikler nedeniyle tüm gruplar içerisinde olaysız sağ kalım açısından en iyi oranlara sahip gruptur $(8,11-14)$.

\section{3-Pre- B hücreli ALL:}

Blastik hücreler intrastoplazmik $\mu$ ağır zinciri taşırlar. TdT pozitiftirler ve çocukluk çağı ALL'lerinin \%1520`sini oluştururlar. Bu immünfenotipik grubun hipodiploidi, beyaz küre sayısı yüksekliği, $t(1 ; 19)$ kromozom anomalisi ile birlikteliği sık görülmektedir. Ki ve MSS nüks oranı fazlayken sağ kalım süresi kısadır $(2,7,11,12,15-18)$.

\section{4-Matür B hücreli ALL:}

Fenotipik ve genotipik olarak iki çeşit $B$ hücreli lösemi vardır. Sık görülen türünde hücre yüzeyinde ek olarak cylgM, slgM, CD19, CD20, CD22, CD79a ve sıklıkla da CD10 bulunur. CD34 ve TdT ise bulunmaz. Morfolojik olarak bu tip L3 morfolojik özelliklerini gösterir. Bu tipinde genetik olarak Burkitt lenfoma için tipik olan 8. kromozom translokasyonları $[\mathrm{t}(8 ; 14)$, $t(2 ; 8), t(8 ; 22)]$ izlenir. Çocukluk ve erişkin ALL'lerin \%1-2'sini oluştururlar. MSS tutulum insidansı daha yüksektir $(2,7,12,14,18)$.

\section{B-T hücreli Akut Lenfoblastik Lösemi:}

T lenfositler yüzeylerinde $C D 3, C D 2, C D 5$ ve $C D 7$ taşırken nükleer bir enzim olan TdT'yi de taşırlar. Bunların dışında $C D 1, C D 4$ ve $C D 8$ de $T$ hücre belirtecidir. Koyun eritrositleri için reseptör taşırlar. CALLA antijeni genellikle negatiftir. Çoğunlukla PAS ile boyanmazlarken asit fosfatazla boyanırlar. Hem çocukluk hem de erişkin dönem ALL vakalarının \%1520'sini oluştururlar. 1 Yaşın altında az görülürler. Çoğunlukla erkeklerde ve yüksek lökosit sayısı ile birlikte görülür. Hastaların \%50-60'ında mediastinal kitle görülür. MSS tutulumu ve ekstramedüller tutulum diğer ALL tiplerinden daha fazla görülür.

\section{Sitogenetik Özellikler:}

\section{1-Akut Lenfoblastik Lösemilerde Sayısal Kromozomal Bozukluklar:}

a-Hiperdiploidiler: Kromozom sayısının 46'nın üzerinde olmasıdır. Kromozom sayısı 47-50 olan hiperdiploidiler \%7-16 oranında görülmekte olup, fazla olan kromozomlar genellikle 8, 13 ve 21 . kromozomlardır. Bu grubun 5 yıllık yaşam beklentisi $\% 80-90$ düzeylerindedir $(1,12,19,20)$.

b-Hipodiploidiler: Kromozom sayısının 45 ve altında olmasıdır. Sayısal anomalilerin \%8'ini tüm kromozomal bozuklukların \%1'lik kısmını oluşturup en çok 20. kromozom kaybıyla birliktedir ve prognozu kötüdür.

Ayrıca akım sitometrisi ile normal hücre ve blastik hücrelerin DNA içeriğinin ölçülüp birbirine oranlanması ile elde edilen orana DNA indeksi denilip bu oran $>1.16$ olması hiperdiploidi lehine yorumlanır. DNA indeksi $<1.16$ olması hipodiploidi lehine yorumlanıp kötü prognostik özellikle birliktedir $(1,2,7,11,12,19-21)$.

\section{2- Akut Lenfoblastik Lösemilerde Yapısal Kromozomal} Bozukluklar:

I-TEL-AML Füzyonu: $t(12 ; 21)$ ile birliktedir. Pre $B$ ALL'lerin \%25'inde saptanır. Prognozu iyidir $(1,2,7$, 19-22).

II-BCR-ABL Füzyonu: $t(9 ; 22)$ olguların $\% 3-5$ 'inde bulunur. Bu translokasyon kötü prognostik özellik gösterir. Tedavide ise ilk remisyona girdikten sonra hızla allojenik Kiт planlanmalıdır $(1,2,7,11,12,20$ 22).

III-E2A-PBX1 Füzyonu: $t(1: 19)$ preB hücreli ALL'lerin \%25in de saptanır. Genellikle yüksek lökosit sayıları ile birliktedir. Yüksek doz metotreksat verilmediğinde prognoz kötüdür $(1,7,13,19-22)$.

IV-MLL-AF4 Gen Rearanjmanı: $t(4 ; 11), t(9 ; 11)$ ve $t(11 ; 19)$ bozukluklarını içerir ve genellikle süt çocuğu döneminde görülür. Tedavi başarısı \%20 kadardır. (1, 2, 7, 11, 12, 19-21).

V-MYC gen bozuklukları: Burkitt lenfoma benzeri özellik gerektirip $t(2 ; 8), t(8 ; 14), t(8 ; 22)$ yapısal bozukluklarını gösterir $(11,12,19-21)$.

\section{KLINIK BELIRTI VE BULGULAR:}

Akut löseminin başlangıç bulgu ve semptomları çok değişik olabilmektedir. Birçok vaka ani başlangıçlı olup bulgular Ki yetmezliğinin derecesi ve ekstrameduller tutulumun genişliğine göre değişmektedir. Hastalık ALL'li çocuklarda herhangi bir prodromal belirti olmadan birdenbire ağır bir klinik tablo şeklinde başlar. Belirtilerin başlaması ile tanının konması arasında 
geçen süre birkaç gün ile birkaç hafta arasındadır (1113). Akut lösemili hastalarda anemiye bağlı halsizlik, solukluk, çabuk yorulma, çarpınt ve efor dispnesi, trombositopeniye bağlı cilt, cilt alt, mukoza ve iç organ kanamaları ve nötropeniye bağlı ateş ve enfeksiyon sıklığında artı̧ görülebilir.

Fizik muayenede anemi bulgusu olarak cilt ve mukozalar soluktur. Genel durumu düşkün görümde olabilir. Takipne ve taşikardi gibi yetmezlik bulguları saptanabilir. İkter çok sık görülmemekle birlikte karaciğer ve dalak infiltrasyonuna sekonder olarak görülebilir. Hepatomegali hem kalp yetmezliğine bağlı hem de lösemik hücre infiltrasyonuna bağlı görülebilir $(1,7,8,11,13,14)$.

Trombositopeniye bağlı kanama deride peteşi, purpura ve ekimoz şeklinde olabilir. Burun, diş eti ve konjunktival kanamalar da sıktr. Trombosit sayısı $20000 / \mathrm{mm}^{3}$ ün altına düştüğü zaman iç organlarda kanama görülebilir. Sıklıkla gastrointestinal sistem, ürogenital sistem, SSS, akciğerler ve retinaya kanama gözlenebilir. Lökostaz varsa SSS ve akciğerlere kanama izlenebilir $(12,14)$.

Granülositopeniye bağlı olarak her türlü bakteriyel, fungal ve protozoal enfeksiyonlar görülebilir. Mutlak nötrofil sayısının $\mathrm{mm}^{3}$ te 500 'ün altnna düştüğü olgularda enfeksiyon riski artar. Deri, diş eti, perirektal bölge, akciğer ve üriner sistem enfeksiyonlarına sık rastlanır. Hastalığın ilerlemesi ve tedaviye bağlı immünsüpresyon nedeni ile firsatçı patojenler ciddi enfeksiyonlara neden olabilirler. Tanı anında hastaların çoğunda ateş vardır $(1,7,11)$.

İştahsızlık ve kilo kaybı da hastaların çoğunda tanı anında vardır. Lösemik infiltrasyon sonucu ortaya çıkan kemik ve eklem ağrıları ile eklem şişliği hastalığın akut eklem romatizması ya da juvenil romatoid artrit ile karışmasına neden olmaktadır $(1,2,7,8,11$ - 13)

Lenfadenopati ve hepatomegali ALL'de sıkça saptanan bulgulardır. T hücreli ALL'de lenf bezleri veya timusta büyüme saptanabilir $(1,2,8,11)$. Özellikle $T$ hücreli lösemide mediastinal kitle \%60 oranında görülebilir, eğer kitle çok büyürse bazı vakalarda vena kava superior sendromu gelişebilir. Bu durumda dispne, stridor, siyanoz, senkop, öksürük, fasial ödem gibi bulgular görülür $(1,7,12,14)$.
Tanı sırasında SSS tutulumu \%5'ten daha az olguda görülür. Tanı sırasında BOS incelemesinde mikrolitrede en az 5 lökosit olması SSS tutulumu lehine değerlendirilir. Hastalar kraniyal sinir paralizisi ve intrakraniyal kanama ile gelebilirler. Genellikle hiperlökositoz, T hücreli ALL ve infant lösemilerde SSS tutulumu sıktir $(1,8,11,14,18)$.

Genitoüriner sistem tutulumuna bağlı testislerde ağrısız büyüme izlenebilir. Sakral köklerin invazyonu ve dorsal ven invazyonu priapizme neden olabilir. Renal infiltrasyona bağlı olarak hipertansiyon ve renal yetmezlik bulguları gelişebilir. Hızlı hücre turnoveri neticesinde artan serum ürik asidine bağlı nefropati gelişirken, kemoterapinin etkisi ile tümör lizis sendromuna bağlı akut böbrek yetmezliği de karşılaşılan bir diğer renal problemdir $(8,11,13,14)$.

\section{LABORATUAR BULGULARI}

Akut lösemilerin karakteristik periferik kan bulguları ileri derecede anemi, trombositopeni ve periferik yaymada blastik hücrelerin varlığıdır. Ancak ilk tanı anında \%20 hastada normal periferik kan tablosu saptanabilmektedir. Anemi en sık ve en erken görülen bulgudur. Anemi normokrom normositer özelliktedir. Anizositoz, poikilositoz ve polikromazi görülebilir. Trombosit sayısı genellikle başlangıçtan beri düşüktür. Vakaların yarısında trombosit sayısı $50000 / \mathrm{mm}^{3}$ ün altnndadır. Akut lösemilerde lökosit sayısı normal, yüksek veya düşük olabilir. Tanı anında yaklaşık \%50 olguda artmış, \%20 olguda 100000/ $\mathrm{mm}^{3}$ ün üzerindedir. Vakaların \%20'sinde ise lökopeni bildirilmektedir $(1,2,7,8,11,13,14)$.

Periferik yaymada ALL'de L1, L2 ve L3 morfolojisinde blastik hücreler değişik oranlarda görülebilir. Çok genç hücrelerle tamamen olgun hücreler bir arada bulunur, dizinin diğer ara hücreleri yoktur. Akut lösemiler periferik yaymada blastik hücre miktarına göre üç şekilde karşımıza çıkarlar; Lösemik grupta olanlarda çevre kanında blast oranı çok yüksektir ve lökosit sayısı yüksektir. Sublösemik şekilde lökosit sayısı normal veya düşük, blastik hücre mevcuttur. Alösemik lösemide çevre kanında blastlara rastlanmaz fakat Ki blastlarla kaplıdır $(2,11,12,14)$. ALL tanısı için Ki aspirasyon örneğinde blastik hücre popülasyonunun $\% 25^{\prime}$ in üzerinde olması gerekir. Akut 
lösemide Ki genellikle hücreden zengin olup, yaygın bir şekilde tek tip blastik hücreyle infiltredir. Eritroid seri ve megakaryositer seri belirgin derecede azalmıştır. Bazen Ki alınamaz. Miyelofibrozis olarak adlandırılan bu durumlarda tanı için Ki biyopsisi yapılmalıdır $(2,7$, $8,11,13)$.

Çevre kanı ve kemik iliğinde görülen lösemik hücrelerin morfolojik özellikleri ve histokimyasal boyamaları sayesinde lösemi tipi ve alt tipi saptanabilir. Histokimyasal boyama akım sitometrinin tanıda kullanılmaya başlanması ile önemini kısmen yitirmiştir. PAS, peroksidaz, esteraz ve sudan black en sık kullanılan histokimyasal boyalardır. Sudan Black boyası, granüllerin çevresindeki fosfolipidleri boyayan nonenzimatik bir boya olup Miyeloperoksidaz (MPO) ile paralellik gösterir. Ancak granüler ALL tanısını destekleyebilir. PAS boyası immatür hücrelerdeki glikojeni boyar. Çoğu lenfoblast PAS pozitif iken AML M6 ve M7 miyeloid seride en çok PAS boyası ile boyanan subgruplardır $(1,7,11)$.

Bundan sonraki aşama akım sitometri ile immünfenoptiplendirme yapma aşamasıdır. Kullanılan kökene özgü antikorlarla önce $T$ veya $B$ lenfoid kökenli olarak ikiye ayrılır. B hücre kökenli ALL'lerde CD19, CD22, CD79a ve HLA-DR'den en az ikisi bulunur. CD 10 (CALLA) antijeni ise \%80-85 ALL'de görülüp iyi prognoza işaret eder. Sitoplazmik ve yüzeyel immünglobulin ağır ve hafif zincirlerinin varlığı matür $B$ hücreli $A L L$ tanısını koydurur $(1,2,7,8,11,14)$. T hücre kökeniyle ile ilgili antijenler $C D 3$ ve $C D 7$ 'dir. Bunlara ek olarak CD2, CD5 ve CD1a ekspresyonu da T hücreli ALL ile ilişkilidir. CD2 ekspresyonu iyi prognozla ilişkili iken CD7 pozitifliği daha çok kötü prognostik özelliğe işaret eder $(1,23)$.

ALL'li çocukların 1/3'ünde bir ya da daha fazla immünglobulin tipinde düşüklük saptanmıştr. Lösemik hücreler invitro immünglobulin sentezini baskılama yeteneğine sahiptirler (24).

Lösemik hücrelerin yüksek turnover hızı pürin metabolizmasında artışına neden olur. Bunun sonucunda tanı esnasında hiperürisemi bazı vakalarda izlenebilir. Yeterli alkalizasyon ve allopürinol tedaviye eklenmezse tümör lizis sendromu ve ürikasit nefropatisi gelişebilir. Akut lösemilerde seyrek olarak hiperkalsemi, hiperpotasemi, hiponatremi gibi elektrolit bozukluklarıda tanı esnasında izlenebilir (1,
$7,14,18)$. Lösemik hücre yıkımı sıklıkla yüksek serum LDH düzeylerine yol açabilir. Tanı esnasında lösemik hücrelerin karaciğeri infiltre etmesi nedeni ile sıklıkla karaciğer enzimlerinde de yükseklik saptanabilir (16).

Yaygın osteoporoz, periost reaksiyonu ve osteolitik lezyonlara ALL'de sıklıkla rastlanır. Kemik lezyonları ağıı olmaksızın radyolojik olarak da saptanabilir. Nadiren kemik tutulumu osteomiyeliti taklit eder ve tanıda karışıklığa neden olabilir $(1,2,8)$.

Tanı esnasında göğüs grafisi özellikle mediasten genişliği ile giden $T$ hücreli ALL açısından yol gösterici olabilir. Hastaların kardiyak tutulum açısından değerlendirilmesi ve kemoterapiye bağlı kardiyak toksisitenin monitörizasyonu açısından ekokardiyografik inceleme önemlidir. Testis ve batn ultrasonu tanı esnasında ek tutulumlar açısından yapılmalıdır. BOS incelemesi SSS tutulumunun varlı̆ı̆ıı ortaya koymak için tanı esnasında yapılmalıdır $(1,7$, $11,14,18)$.

\section{AYRICI TANI}

Dikkatli hikaye alma, fizik muayene, periferik yayma ve Ki bulguları ile olguların büyük çoğunluğuna tanı konulabilmektedir. Viral enfeksiyonlar, idiyopatik trombositopenik purpura, aplastik anemi, miyelodisplastik sendrom, juvenil romatoid artrit, metastatik solid tümörler, kollojen doku hastalıkları gibi bazı hastalıklar ayırıcı tanıda akla getirilmelidir. Lenfoma, rabdomiyosarkom, nöroblastom gibi solid tümörler de ayırıcı tanıda unutulmamalıdır.

\section{PROGNOZ}

Çocukluk çağı ALL'inde prognoza etki eden belli başlı faktörler şunlardır;

1-Yaş: Önemli bir prognostik faktördür. 1-10 yaş arası prognoz iyi iken, 1 yaş altı ve 10 yaş üstünde prognoz daha kötüdür. 1 yaş altı olgularda, hiperlökositoz, SSS tutulumunun sıklığı ve MLL gen rearrengement pozitifliği daha sık görülmekte olup bu durumlar kötü prognoz ile ilişkilidir. 
2-Lökosit sayısı: Yapılan çalışmalarda periferik kanda lökosit sayısının 50000/mm3 üzerinde olmasının kötü prognostik faktör olduğu bildirilmiştir (25).

3-İmmunfenotipleme: Matür $B$ hücreli ve $T$ hücreli ALL'de prognoz genellikle daha kötüdür. $B$ hücreli ALL'ler içinde erken preB ALL'nin (sitoplazmiklg-) prognozu, preB ALL'ye (sitoplazmiklg+) göre daha iyidir (26). Yeni tanı alan olguların \%15-30'unda aberran miyeloid antijen ekspresyonu mevcuttur. Ancak bunun bağımsız bir risk faktörü olmadığı bildirilmiştir. Fenotipik olarak kötü prognostik olduğu belirtilen olgularda, yoğun kemoterapi rejimlerinin uygulanması ile giderek artan oranda başarı sağlanmaktadır.

4-Kromozomal anormallikler: Çocukluk çă̆ı ALLvakalarında, iyi prognostik özellik gösteren 2 anormalik bildirilmiştir. Bunlardan biri yüksek hiperdiploidi kromozom varlığı ve DNA indeksinin 1.16'nın üzerinde olması, diğeri ise $t(12,21)$ (TEL/ AML1 füzyonu) bulunmasıdır. Kötü prognostik özellik gösteren kromozomal anormallikler; hipodiploidi ile birlikte MLL (11q23) gen yeniden düzenlenmesi ve $\mathrm{t}(9 ; 22)$ varlığıdır.

5-Indüksiyon kemoterapisine erken cevap: Indüksiyon tedavisine cevap, morfolojik inceleme veya FISH, PCR gibi hassas yöntemlerle yapılabilmektedir. BFM grubunun çalışmasında indüksiyon tedavisinin 8.gününde steroide cevap olarak periferik kandaki blasik hücre sayısı >1000/mm3 olanlarda prognozun daha kötü olduğu bildirilmiştir (27). Benzer şekilde tedavi başlangıcından 7-14 gün sonra alınan kemik iliğinde lösemik hücrelerin görülmesi de önemli bir kötü prognoz işareti olarak bildirilmiştir (28). PCR veya flowsitometri ile tedavinin erken döneminde minimal rezidüel hastalık (MRD) değerlendirmesi bağımsız bir risk faktörü olarak belirlenmiştir (29). MRD pozitif hastalarda tedavi cevabı ve prognoz daha kötüdür.

6-Tanıda SSS tutulumunun olması: ALL'li çocukların \%15-20'sinde tanıda SSS tutulumu mevcuttur ve kötü prognoz ile ilişkilidir.

\section{AKUT LENFOBLASTIK LÖSEMI TEDAVISi}

Remisyon- indüksiyon: Glukokortikoid, vinkristin (VCR) ve L-asparaginaz uygulamasını kapsar. Amaç hızlı bir şekilde Ki'ni remisyona sokmaktır. Tam remisyon; blastların çevre kanında görünmemesi ve kemik iliğinde $\% 5$ 'ten az olması, periferik kan değerlerinin normale gelmesi, organomegalinin kaybolması ve hastanın normal performansının geri dönmesi olarak tanımlanır. İkili kemoterapilerle (VCR+Prednizolon) remisyon \%85 iken L-asparaginaz, antrasiklin veya her ikisinin birden tedaviye eklenmesi ile bu oran $\% 95$ düzeylerine çekilmiştir $(1,11,30,31)$.

MSS koruma tedavisi: Genellikle indüksiyon dönemi ile beraber başlayıp daha sonra da devam etmektedir. Damar içine uygulanan kemoterapinin BOS'a geçişinin yetersiz olduğu görüldüğü için, tanıda SSS tutulumu olan hastalara BOS'ta blastlar kaybolana kadar haftada 1-2 kez intratekal tedavi uygulanmalıdır. Yüksek riskli hastalara, tanıda SSS tutulumu olmasa bile, tedavinin belli bir döneminde profilaktik olarak 1800 cGy radyoterapi ile beraber tekrarlayan intratekal kemoterapilerin (metotreksat, ARA-C, prednisolon) verilmesi SSS nüksünü belli oranda azaltmıştır. Standart riskte olan hastalar için ise radyoterapi önerilmemekte, daha az sıklıkta intratekal tedavi önerilmektedir (1).

\section{Güçlendirme tedavisi (konsolidasyon/} intensifikasyon): $\mathrm{Bu}$ tedavinin amacı hastalık bulgularını daha da azaltarak, nüksü önlemektir. $\mathrm{Bu}$ durumda ya metotreksat ve ARA-C gibi ilaçlar kullanılmakta ya da indüksiyon tedavisinin benzeri bir tedavi verilmektedir. Güçlendirme fazı, indüksiyon sonrasında olabileceği gibi daha geç dönemde de verilebilir.

İdame tedavisi: Daha düşük dozlarda ilaçlar uygulanarak risk gruplarına göre tedavinin en az 2 yıl devam etmesi amaçlamaktadır. İdame tedavide kullanılan ilaçlar merkaptopurin ve metotreksatdır. Bunun yanı sıra aralıklı olarak steroid, vincristin, etoposid ve ARA-C de idame tedavisi sırasında kullanılmaktadır.

Tedavi Komplikasyonları: Tanı anındaki major komplikasyonlar, metabolik bozukluklar, kan sayımındaki anormallikler ve organ infiltrasyonlarına bağlıdır. Tedavi sırasında gelişen komplikasyonlar ise bunlara ilaveten miyelosupresyon sonucu artmış enfeksiyon riski ve ilaçların toksik etkileri olarak sıralanabilir. 


\section{KAYNAKLAR}

1. Elmas SA, Yetgin S, Kuskonmaz B, et al. Akut lösemi. Katkı Dergisi 2004;26(2):372- 403.

2. Poplack DG, Margolin JF .Management of common cancers of childhood in: Poplack, editors. Principles and Practice of Pediatric Onkology I. Philedelphia Saunders, 1997:409-504.

3. Apak H. I.Ü.Cerrahpasa Tıp Fakültesi Tıp Egitimi Sempozyum No:45. Kasım 2005:155-9.

4. Artan $A E$, Sengelen $M$, Vaizoglu $S A$. Önlenebilir çocukluk çağı kanserleri. Cumhuriyet Üniversitesi Tıp Fakültesi Dergisi 2004;26(1):48-54.

5. Bennet JM, Catovsky D, Daniel MT. Proposals for the classitification of the acute leukemias. $\mathrm{Br} \mathrm{J}$ Haematol 1976;33(4):451-8.

6. Bennet JM, Catvsky D, Daniel MT, et al. FrenchAmerican-British Cooperative Group:The Morphological classification of acute lymphoblastic leukemia: concosdance among observers and clinical correlations. Br J Haematol 1981:47(4):533-61.

7. Lanzkowsky P. Leukemias. Manual of pediatric hematology oncology. 4th Edition, Elseiver Academic Pres, 2005:415-50.

8. Orkin SH, Fisher DE, Look AT, et al. Hematology of infancy and childhood. 7th Edition, Philedelphia Saunders. Acute lymphoblastic and myeloblastic leukemia in: Nathan DG (Editors). 2009:298-374.

9. Lilleyman JS, Hann IM, Stevens RF, et al. The French American British morphological classification of childhood lymphoblastic leukemia and its clinical importence. J Clin Pathol 1986;39(9):998-1002.

10. Miller DR, Krailo M, Bleyer WA. Prognostic implications of blast cell morphology in acute lymphoblastic leukemia:A report form the Children's Cancer Study Group. Cancer Treat Rep 1985;69(10):1211-21.

11. Ching H Pui. Childhood Leukemias. St Jude Children's Research Hospital Memphis, Tennesse, Cambridge Universty Pres, 2006;2-190.

12. Celkan T. Akut lösemiler. Klinik Gelisim Dergisi 2007;20(2):14-32.

13. Licthman MA, Beutler E, Selishon U, et al. Acute Lymphoblastic leukemia and acute myeloid leukemia. Williams Hematology. 7th Edition, 2007:87-91.

14. Owen PS, Ian MH. Clinical features and thrapy of lymphoblastic leukemia. Pediatric Hematology. 3th Edition, 2006;20:450-87.

15. McKenna RW. Multifaceted aproach to the diagnosis and classification of acute leukemia. Clin Chem 2000;46(8):1252-9.
16. Pui CH, Williams DL, Roberson PK, et al. Correlation of karyotype and immunophenotype in childhood acute lymphoblastic leukemia. J Clin Oncol 1988:6(1):56-61.

17. Puı CH, Williams DL, Kalwinsky DK, et al. Cytogenetic features and serum lactic dehidrogenase level predict a poor treatment outcome for children with PreB cell. Leukemia 1986;67(6):1688-92.

18. Kantarjian HM, Wolff RA, Koller CA. The MD Anderson Manual of Medical Oncology. 2007:192-3.

19. Arıco M, Valsecchi MG, Camıtta B, et al. Outcome of treatement in children with philedelphia choromosome-positive acute lymphoblastic leukemia. N Engl J Med 2000;342(14):998-1006.

20. Fıratlı T.Akut lösemi etiyopatogenezi: Sitogenetik. XXX. Ulusal Hematoloji Kongresi 2006:119-26.

21. Kale G, Coskun T, Yurdakök M. Pediatride tanı ve tedavi Hacettepe uygulamaları. 2009:486-93.

22. Puı CH. Childhood leukemia. N Engl J Med 1995;332(24):1618-30.

23. Raimondi SC, Behm FG, Roberson PK, et al. Cytogenetics of T cell leukemia. Blood 1988;72(5):1560-6.

24. Leikin S, Miller D, Sather H. Immunologıc evaluation in the prognosis of acute lymphoblastic leukemia. A report from childrens cancer study group. Blood 1981;58(3):501-4.

25. Smith $M$, Bleyer $A$, Crist $W$, et al. Uniform criteria for childhood acute lymphoblastic leukemia risk classification. J Clin Oncol 1996;14(2):680-1.

26. Crist $\mathrm{W}$, Boyett J, Roper $\mathrm{M}$, et al. Pre-B cell leukemia responds poorly to treatment: a pediatric oncology group study. Blood 1984;63(2):407-14.

27. Schrappe $M$, Reiter A, Zimmermann $M$, et al. Longterm results of four consecutive trials in childhood ALL performed by the ALL-BFM study group from 1981 to 1995. Berlin-Frankfurt-Munster. Leukemia 2000;14(12):2205-22.

28. Gaynon PS, Desai AA, Bostrom BC, et al. Early response to therapy and outcome in childhood acute lymphoblastic leukemia: a review. Cancer 1997;80(9):1717-26.

29. Coustan-Smith E, Behm FG, Sanchez J, et al. Immunological detection of minimal residual disease in children with acute lymphoblastic leukaemia. Lancet 1998;351(9102):550-4.

30. Puı CH, Evans WE. Drug therapy treatment of acute lymphoblastic leukemia. N EngI J Med 2006;354(2):16678.

31. Rubnitz JE, Puı C-H. Childhood acute lymphoblastic leukemia. The Oncologist 1997;2(6):374-80. 
